DOI: $10.22363 / 2313-0660-2020-20-1-158-169$

Research article

\title{
Small Arms and Light Weapons (SALW) and Transnational Crime in Africa
}

\author{
A.J. Falode \\ Lagos State University, Lagos, Nigeria
}

\begin{abstract}
This paper analyses the role of the arms trade in the growth and spread of transnational crime in Africa. The work shows that the proliferation and ready availability of Small Arms and Light Weapons (SALW) on the continent is contributing in no small measure to political, economic and social insecurity in Africa. Major transnational crimes that the work identifies in Africa include drug trafficking, human and people trafficking, environmental crimes, arms trafficking and stolen vehicle trafficking. The work uses qualitative research methodology, which involves the extensive collection, collation and analysis of secondary data, to capture the essence and scope of the impacts of SALW on the growth and spread of transnational crime on the continent. A major and significant contribution of the work is the crucial connection that it establishes between the proliferation of SALW and the high incidence and recurrence of transnational crime in Africa. The work shows the destabilizing impacts of the proliferation of SALW in Africa and how these is contributing to the recurrence of conflicts and criminal activities on the continent. In its conclusion, the work recommends that in order for states on the continent to be able to proactively tackle transnational crime and the proliferation of SALW, they will have to do the following: carry-out an extensive and critical survey to create a database that will identify the nature of the different transnational crime that is carried-out in each regions; create (where it does not exist) and, strengthen and implement (where it exist) legislations and laws designed to tackle transnational crime; and encourage interagency cooperation and coordination among the affected states in the regions.
\end{abstract}

Key words: small arms and light weapons (SALW), Africa, transnational crime, instability

For citation: Falode, A.J. (2020). Small Arms and Light Weapons (SALW) and Transnational Crime in Africa. Vestnik RUDN. International Relations, 20 (1), 158-169. DOI: 10.22363/2313-0660-2020-20-1-158-169

Научная статья

\section{Влияние распространения стрелкового оружия и легкого вооружения на транснациональную преступность в Африке}

\author{
А.Дж. Фалоде \\ Государственный университет Лагоса, Лагос, Нигерия
}

\begin{abstract}
В данной статье анализируется роль торговли оружием в росте и распространении транснациональной преступности в Африке. Автор показывает, что распространение и доступность стрелкового оружия и легких вооружений (СОЛВ) на континенте в немалой степени способствуют политической, экономической и социальной нестабильности в Африке. В качестве основных видов криминальной деятельности в Африке в данной работе выделяются торговля наркотиками, торговля людьми, экологические преступления, торговля оружием и сбыт краденных транспортных средств. В работе используется методология качественных исследований, которая включает в себя сопоставление и анализ вторичных данных, что позволило раскрыть сущность и масштабы воздействия распространения СОЛВ на рост и распространение транснациональной преступности на континенте. Автору удалось показать связь, которая существует между распространением СОЛВ и высоким уровнем транснациональной преступности в Африке. Доступность СОЛВ, а также торговля оружием создают дестабилизирующую обстановку, в которой практически невозможно успешно бороться с транснациональными криминальными сообществами.
\end{abstract}

(C) Falode A.J., 2020

This work is licensed under a Creative Commons Attribution 4.0 International License.

https://creativecommons.org/licenses/by/4.0/ 
В заключение автор приходит к выводу, что для активной и успешной борьбы с транснациональной преступностью и распространением СОЛВ на Африканском континенте государствам необходимо сделать следующее: провести обширный и критический опрос населения для создания базы данных, которая определит характер различных транснациональных преступлений, совершаемых в каждом регионе Африки; создавать (там, где его нет) и укреплять и применять (там, где оно существует) законодательство и законы, направленные на борьбу с транснациональной преступностью; поощрять межведомственное сотрудничество и координацию между пострадавшими государствами в отдельно взятых регионах.

Ключевые слова: стрелковое оружие и легкие вооружения (СОЛВ), Африка, транснациональная преступность, нестабильность

Для цитирования: Falode A.J. Small Arms and Light Weapons (SALW) and Transnational Crime in Africa // Вестник Российского университета дружбы народов. Серия: Международные отношения. 2020. Т. 20 . № 1. C. 158 -169. DOI: 10.22363/2313-0660-2020-20-1-158-169

\section{Introduction}

Transnational crimes are crimes that are committed across the national boundaries of states [Sheptycki, Wardack 2005: 146]. Such crimes are sometimes committed by individuals or groups in one state across the borders of several others [Brown 2020: 1-12]. This has come to define the nature of most crimes committed across borders in Africa in the 21st century. Transnational crime is diverse, and it includes: drug trafficking, human and people trafficking, advanced fee and internet fraud, maritime piracy, illegal manufacture of firearms, trafficking in firearms, banditry, theft, oil smuggling and cattle-rustling ${ }^{1}$. Most of these transnational crimes are carried-out using small arms and light weapons (SALW). Small arms and light weapons refer to those weapons that can be carried by one or two persons, mounted on a vehicle or lugged by an animal from one place to another [Kumar 2008: 787]. These weapons include revolvers, rifles and submachine guns. The use of SALW has contributed to the breakdown of law and order, institutions, socio-economic and political life across the African continent. The major impacts of transnational crime in Africa, like in other regions of the world that is affected, has been the collapse of state institutions, emergence and prevalence of civil wars, ethnic religious crisis, piracy, banditry and farmers-herders conflicts across the continent [Reitano 2018: 23-35].

\footnotetext{
1 Transnational Organized Crime in the West African Region // United Nations Office on Drugs and Crime, 2005. P. 19-31. URL: https://www.unodc.org/pdf/ transnational_crime_west-africa-05.pdf (accessed: 02.07.2019).
}

\section{Guns and Transnational Crime in Africa: Conspectus}

There is an abundance of literature on the topic of guns, arms trade and transnational crime in Africa. C. Pumphrey and R. Schwartz-Barcett show the different origins of conflicts in various parts of the continent [Pumphrey, SchwartzBarcett 2003]. Apart from providing a general overview of the nature and forms of conflicts, they also analyse its typology. The authors further identify the important role that nongovernmental organizations can play in the mitigation and eradication of conflicts and conclude that a holistic and systemic continentwide approach is needed to tackle the menace.

F.L. Keili traces the origins and proliferation of small arms and light weapons (SALW) in West Africa [Keili 2008]. The author identifies the various factors such as lax arms control and porous borders that have enabled the spread and availability of dangerous SALW in the region. F.L. Keili argues that West Africa had been particularly hard-hit by the proliferation of SALW. Apart from the fact that the availability of SALW has led to the frequent occurrences of conflicts in the region, SALW has also affected socio-economic and political development.

P. Lloyd, B. Simmons and B. Stewart argue that the best way to tackle transnational crime is through the strengthening of the rule of law [Lloyd, Simmons, Stewart 2012]. This rule of law has both domestic and international dimension, according to the authors. Since transnational crime cuts across states boundaries, the authors posit that a credible domestic law and a strengthened international or regional law, arrived at through multilateral diplomacy, will go 
a long way to tackle an important aspect of transnational crime known as human trafficking.

A. Ayissi and I. Sall show the different aspects of the origin, growth, impact and challenges that SALW pose in West Africa [Ayissi, Sall 2005]. The authors, among other things, details the mechanism that the regional body, Economic Community of West African States (ECOWAS) has put in place to tackle and check the proliferation of illegal arms [Ayissi, Sall 2005: 31-34]. It further shows the various efforts that Nigeria has put in place to combat the proliferation of SALW in the country and the West African sub-region. Such efforts include the creation of dedicated military and para-military agencies and the inclusion of civil society and the media in the fight against the proliferation of illegal arms [Ayissi, Sall 2005: 111-117].

E. Chelule has shown the impacts of proliferation on socio-economic and political development on the continent [Chelule 2014]. The author traces the sources of SALW in Africa and further identifies the various factors responsible for its proliferation. Chelule argues that the spread and easy availability of SALW has been responsible for the incessant and longduration of conflicts on the continent. According to the author, the mechanisms, such as Firearms Protocol of $2005^{2}$, is both inadequate and ineffective. A major factor responsible for this is the fact that weapon-producing states like the United States, Russia, China and Egypt have actively undermined the effectiveness of the Protocol since it directly affects their overall economic profitability.

From the foregoing, one can see that there is plenty of literature on SALW and transnational crime in Africa. However, what is missing from the reviewed works is a research that focuses on the link or the symbiotic or enabling relationship between the proliferation of SALW and transnational crime on the continent. Thus, it is this lacuna that this research tackles.

2 Protocol against the Illicit Manufacturing of and Trafficking in Firearms, Their Parts and Components and Ammunition, supplementing the United Nations Convention against Transnational Organized Crime (Firearms Protocol), 11 July $2001 / /$ The United Nations. URL: https://treaties.un.org/doc/source/RecentTexts/18-12 _c_E.pdf (accessed: 02.07.2019).

\section{Methodology}

The research relies heavily on qualitative research methodology. This involves the collection, collation, review and interpretation of secondary materials like textbooks, journal articles, gazettes, white papers and internet articles on transnational crime and proliferation of SALW in Africa. It further involves the carryingout of extensive and critical content analysis of extant literature on uncontrolled arms, impacts of SALW on governance and economic development, and the different types and impacts of transnational crime on Africa. The qualitative methodology used ensured the collection, collation and interpretation of data on both SALW and transnational crime. White papers and official documents from both within and outside the continent on countering the proliferation of SALW and combating transnational crime from such international governmental organizations like the

United Nations (UN), African Union (AU) and ECOWAS were extensively used in the analysis. The integration and analysis of multiple data sources provides the most accurate picture of what is occurring on the continent. Moreover, the use of multiple data sources allowed for cross-referencing, information verification and corroboration. However, the research is limited by the non-availability of accurate, reliable, consistent and up-to-date empirical data on the extent and volume of the two vices. This is not surprising since the main actors involved in the illicit transnational trade and arms proliferation are predominantly non-state actors, who, due to the nature of their transactions, would not want such data to be readily and easily accessible.

\section{Transnational Crime}

Transnational crime covers virtually all profit-motivated criminal actions of an international nature where more than one country is involved ${ }^{3}$. A crime is transnational if it is

${ }^{3}$ Transnational Organized Crime - The Globalized Illegal Economy // United Nations Office on Drugs and Crime (UNODC). 2012. URL: http://www.europarl. europa.eu/document/activities/cont/201207/20120717ATT 49047/20120717ATT49047EN.pdf (accessed: 02.07.2019). 
perpetrated in more than one state and it has substantial effect in more than one state. Transnational crime threatens peace and human security, leads to human rights being violated and undermines the economic, social, cultural, political and civil development of societies all over the world 4 .

Although, there is no universal definition of transnational crime, researchers have agreed that it has some basic discernible features: perpetrators, objects, motive, digital signals and subjects [Stoica 2016: 14]. The perpetrators are those who carry-out the crime across national boundaries; the object is the illicit good that is traded across national borders - this could be manufactured within the country or the country could be used as a transit hub; the subject is the foreign element that is engaged in the illicit act; the motive refers to the gains to be had from such acts - this could be monetary, political, economic or religious; and the digital signals refer to the use of electronic means to steal or wire money from financial institutions.

Transnational crime has three distinct features:

- it has extensive trans-border connections;

- it has the capacity to challenge national and international authorities;

— it operates at both regional and global levels [Stoica 2016: 14].

These three features, as will be shown, have been displayed in the nature of the transnational crime that is obtainable in Africa. Different theoretical models have been used to explain the occurrence of transnational crime [Ellis, Shaw 2015: 515]. However, two of these models, Realism and Liberal theories that are applicable to Africa will be explained here. The Realism model argues that transnational crime at its core is a continuation of economic activities using illicit methods like violence, blackmailing and intimidation. The Liberal model argues that globalization and economic liberalization are in

4 Transnational Organized Crime - The Globalized Illegal Economy // United Nations Office on Drugs and Crime (UNODC). 2012. URL: http://www.europarl. europa.eu/document/activities/cont/201207/20120717ATT 49047/20120717ATT49047EN.pdf (accessed: 02.07.2019). the core of the paradigm that have encouraged and enabled transnational crime to flourish. The ease of trans-border communications and multilateral trading agreements between and among states have made it possible for perpetrators to carry-out their illicit activities. This is particularly true for Africa where regional arrangements like the ECOWAS have made it possible for SALW to proliferate unchecked in the sub-region. These two major models provide the theoretical rationale for the high incidence and successes of transnational crime that has been recorded in Africa.

\section{Factors Responsible for Transnational Crime in Africa}

The following factors are responsible for transnational crime in Africa: Relative Deprivation, Globalization, Demand and Supply Cycle and Regional Commitments.

1. Relative Deprivation. Most economies in Africa are poor and the governments on the continent have done a poor job of lifting the citizen out of the poverty trap. Unemployment that is rife in most cities on the continent has created a high level of social inequality and disparity. The desire to escape the poverty trap is a major driver for such transnational crimes like maritime piracy, human trafficking, drug trafficking and arms trafficking on the continent. This explains the high incidence of transnational crimes in both West and East Africa. Countries like Nigeria, Niger, Sierra Leone, Somalia and Guinea have been plagued by arms trafficking and maritime piracy, among others.

2. Globalization. Globalization removes borders between states and promotes economic interdependence that is devoid of any serious artificial trade barrier [Zabyelina 2009: 11-22]. This is in itself a good thing, however, it then becomes a problem when the perpetrators put the free movement of people and capital into nefarious uses. These include human trafficking, arms trafficking and other illegal and illicit activities. Countries like Nigeria, Somalia, Kenya and Libya have experienced these aspects of transnational crime in one form or the other, contributing to political and economic instability 
in the sub-regions where these countries are located.

3. Demand and Supply Cycle. This is a very important factor that is responsible for the high incidence of transnational crime in Africa [Madsen 2009]. The continent is riven with pockets of conflicts that range from civil wars to ethno-religious conflicts, from terrorism to boundary disputes and farmers-herders conflicts. These conflicts require that the combatants have adequate resources (weapons) to prosecute their wars. This is the demand aspect of the cycle. The perpetrators now step in to provide the needed weapons. This is the supply aspect of the cycle. Of course, the more the demand is met, the more the conflict rages and the more the combatants demand for more weapons from the supplier. This has led to an unending circle of violence on the continent. Moreover, such conflicts that have been enabled by the proliferation of SALW will further ensure the commission of other transnational crime like drug trafficking and human trafficking, and the violation of human and international rights. This point shows the important connection between guns (SALW) and transnational crime on the African continent. The guns aid the commission of these crimes on a greater and larger scale. This is the experience of Somalia in the Horn of Africa and Nigeria in West Africa.

4. Regional Integrative Organizations. This is another major factor that has aided the spread of transnational crime on the continent. Most countries on the continent belong to various regional and continental organizations. For example, there is ECOWAS in West Africa and Southern African Development Commission (SADC) in Southern Africa. By virtue of their memberships of these economic unions, African states have little or no barrier to the free flow of goods, services and capital in the sub-regions. Since border security checks are often relaxed as a result, or with some being poorly manned, perpetrators have found it easier to move illicit goods in the regions from one state to another [OECD 2018]. This has been the experience of Nigeria with its neighbours such as Benin, Chad and Niger in West Africa. Illegal weapons have flowed through Nigeria's borders because its membership of ECOWAS made it compulsory for her to grant unimpeded access to goods entering from neighbouring countries.

\section{Guns: Small Arms and Light Weapons (SALW)}

Most transnational crime in Africa are carried-out with the aid of SALW. Civil wars in both Nigeria and the Democratic Republic of the Congo in the 1960s were fought with SALW. Maritime piracy on both the Gulf of Guinea and the Horn of Africa are carried-out using SALW. Small arms and light weapons have aided and enabled the spread and commission of transnational crimes on the continent [Bourne 2005]. It facilitates and enables armed conflict, terrorism and transnational crime in Africa. So, what are SALW?

Small arms are those weapons that can be carried by one or two persons that is mounted on a vehicle or carried by a pack animal from one place to the other [Kumar 2008: 787]. The term is used for three major sub-divisions of weaponry: small arms, light weapons and ammunition and explosives [Kumar 2008: 787]. Examples of small arms are revolvers, self-loading pistols, rifles, sub-machine guns and light machine guns.

All these weapons, it should be noted have featured regularly in the transnational crime that has ravaged Africa since the 1960s. For example, in the West African states of Nigeria, Cameroon, Chad and Niger, Boko Haram has used submachine guns, light machine guns and explosives in its various criminal attacks. Al-Shabaab has used small arms like explosives, sub-machine guns, rifles and light machine guns in its attacks against East African states like Somalia and Kenya. Heavy machine guns, hand grenades and mounted grenade launchers, anti-tank guns, and portable launchers of anti-aircraft missile system are good examples of light weapons. Light weapons have been used by various terrorist groups in East, Central and West Africa. Such weapons have aided and prolonged the duration of civil conflicts that have ravaged different countries on the continent. Small arms and light weapons are used by various groups across Africa: militaries, insurgents, terrorists, vigilantes, herders, bandits and transnational criminals. 
Such weapons have some basic characteristics that make them to be appealing to perpetrators who carry-out transnational crime in Africa [Jeffrey, Klare 1998]:

- They are of low cost and widely available. The porous nature of Africa's borders makes it easier for such weapons to be transferred from one state to the other;

- They are easy to use and maintain. The maintenance requires little or no technical skill. This characteristic of the SALW is significant in the African setting because most of those that use such weapons in transnational criminal enterprises are from the unskilled or educationally disadvantaged section of the society;

- They are concealable and easy to carry from one location to the other.

The highlighted characteristics show why SALW has been the weapon of choice for perpetrators like terrorists, bandits, herders and criminals that have been involved in such transnational crime like maritime piracy, human trafficking, cattle rustling, drug trafficking and mineral trafficking across the borders of some states in Africa. There is no hard data on the total number of SALW on the continent. Different scholars, agencies, non-governmental organizations and governmental organizations have given various estimates as to the total number of SALW on the continent. Some non-governmental organizations that tracks the proliferation of arms all over the world have put the tally in the world at approximately 875 million $^{5}$. While a Gun Policy data puts the total number of licit and illicit arms in Africa at 100 million in $2016^{6}$.

But, a 2019 Small Arms Survey (SAS) and AU study titled "Weapons in Compass: Mapping Illicit Small Arms Flows in Africa" estimates the illegal SALW floating around on the continent at 40 million $^{7}$. As it is, it's very difficult to put a

\footnotetext{
${ }^{5}$ Weapons and Market // Small Arms Survey. URL: smallarmssurvey.org/weapons-and-markets.html (accessed: 07.01.2020).

${ }^{6}$ Armed Violence and Guns in Africa // GunPolicy.org. URL: https://www.gunpolicy.org/firearms/region/africa (accessed: 07.01.2020).

${ }^{7}$ Kuwonu F. Small Arms Fuelling Deadly Communal Violence // African Renewal. December - March 2019-2020. URL: https://www.un.org/africarenewal/
}

specific number to the amount of illicit SALW in Africa. However, what is not in doubt, as this research will subsequently show, is the fact that the proliferation of SALW has contributed to political, economic and social instability, and the high incidence of transnational crime on the continent.

\section{Transnational Crime in Africa: An Overview}

Two major defining features of the $21 \mathrm{st}$ century are market liberalization and political democracy [Lloyd, Simmons, Stewart 2012: 153-180]. The Market liberalization aspect that guarantees a more open and almost borderless trading environment among the different states on the continent is a major factor responsible for the exponential growth of transnational crime in Africa. As cost of undertaking transactions has fallen, the opportunities for illicit traders to operate unrestricted across borders has also grown [Mystris 2019: 482 — 487].

Transnational crime in turn creates growing challenges for national authorities at all levels, from foreign policy and security establishments to law enforcement authorities and border control officials [Lloyd, Simmons, Stewart 2012: 153]. This has constituted a serious threat to good governance and state sovereignty across the continent. The major transnational crimes in Africa are drug trafficking, human trafficking, environmental crime, artefact trafficking, financial crimes, counterfeit goods, counterfeit pharmaceuticals, cyber-attacks hacks on financial institutions, maritime piracy and automobile trafficking ${ }^{8}$. The connection between these transnational crime and guns is that SALW enables the commission of some of the more egregious crimes and further makes it difficult for the various national security agencies on the continent to combat them.

magazine/december-2019-march-2020/small-arms-fuelingdeadly-communal-violence (accessed: 08.01.2020).

${ }^{8}$ Overview of Serious and Organized Crime in Africa // Interpol. 29.10.2018. P. 10-28. URL: https://www.interpol. int/content/download/12850/file/Overview\%20of\%20S erious $\% 20$ and $\% 20$ Organized $\% 20$ crime $\% 20 \mathrm{in} \% 20$ AfricaEN.pdf (accessed: 02.07.2019). 
1. Drug Trafficking. The African continent is both a growing global transit hub for the trafficking of illegal drugs en route to other continents and a market where drugs are abused. Drugs like cocaine, heroin, cannabis, and synthetic drugs like Tramadol and methamphetamine are trafficked within and outside the continent. For example, Western, Eastern and Northern Africa are transit regions for cocaine and other drugs from South America9. Africa is also the transit hub for heroine destined for Europe and coming from Asia. Likewise, cannabis is both trafficked within and outside the continent. In 2016, Nigeria was discovered to be the main hub for the production and distribution of methamphetamine in the sub-region ${ }^{10}$. The link between drug trafficking and SALW is that the transnational criminals would need such weapons to protect their merchandise during transit across the different African borders. In the process, such weapons are allowed to proliferate unchecked across the continent's borders.

2. Human and People Trafficking. These are two important transnational crime that occur across Africa. Women (for labour and sex), men (for labour) and boys and girls (for labour, sex and child soldiers) are trafficked across different borders on the continent; and at other times trafficked to Western Europe and the Middle East. For example, Cameroon is an important collation and transit point for women and girls from Western Africa destined for Europe ${ }^{11}$. Ivorian nationals are trafficked to North Africa, especially Tunisia, to be exploited as labour and sex slaves ${ }^{12}$. Almost all African countries are

\footnotetext{
${ }^{9}$ World Drug Report 2017 // United Nations Office on Drugs and Crime (UNODC). URL: https://reliefweb.int/ report/world/unodc-world-drug-report-2017 (accessed: 02.07.2019).

10 Super Laboratory: NDLEA Arraigns 4 Mexicans, 5 Nigerians // National Drug Law Enforcement Agency Official Website. 2016. URL: https:/www.ndlea.gov.ng/ new-and-event/super-laboratory-ndlea-arraigns-4mexicans-5-nigerians/ (accessed: 02.07.2019).

112017 Trafficking in Persons Report - Cameroon // United States Department of State Official Website. URL: https:/cm.usembassy.gov/official-reports/traffickingpersons-report-cameroon/ (accessed: 02.07.2019).

12 Victims of Trafficking in the central Mediterranean Route: Focus on Women from Cote d'Ivoire, from the
}

affected by this particular crime due to the labour-intensive extractive industries, porosity of the borders and poverty ${ }^{13}$. This particular transnational crime also contributed to the proliferation of SALW on the continent due to the fact that the perpetrators require such weapons to protect their subjects from one African border to the other. Additionally, the subjects are sometimes killed, and their organs harvested and trafficked across the continent's borders.

3. Environmental Crimes. Environmental crimes are of two types: exploitation of natural resources and wildlife crimes ${ }^{14}$. Exploitation of natural resources cover illegal lumbering and that of wildlife covers that of poaching of different species of animals. Illegal lumbering not only leads to deforestation with serious environmental consequences, it also leads to the loss of tax revenue and economic opportunities that will further entrench poverty. This is an important transnational crime with serious deleterious ramifications for the countries in Africa. For example, over 120 companies were found to be guilty of illegal logging activities in Mozambique alone in March $2017^{15}$. Cameroon made close to $82.6 \mathrm{mln}$ euros in 2016 from the fines of companies found culpable of violating the country's forestry law ${ }^{16}$.

Interestingly, terrorist groups like AlShabaab in Somalia (East Africa) and rebel

Trafficking in Tunisia to the Risk of Re-trafficking in Italy // IOM Briefing. September 2019. URL: https:/italy.iom.int/sites/default/files/news-documents/IOM Briefing Victims of Trafficking.pdf (accessed: 02.07.2019).

13 Overview of Serious and Organized Crime in Africa // Interpol. 29 October 2018. P. 10-28. URL: https://www.interpol.int/content/download/12850/file/ Overview\%20of\%20Serious\%20and $\% 20$ Organized $\% 20$ crime \%20in\%20Africa-EN.pdf (accessed: 02.07.2019).

${ }^{14}$ Ibid.

${ }^{15}$ Mozambique Battles Illegal to Save Tropical Forests // Agence France - Presse. April 27, 2017. URL: https://www.news24.com/Africa/News/mozambiquebattles-illegal-logging-to-save-tropical-forests-20170426 (accessed: 02.07.2019).

${ }^{16}$ Cameroon publishes data on illegal logging cases and fines // FLEGT. August 8, 2016. URL: http://www.flegt.org/news/content/viewItem/cameroonpublishes-data-on-illegal-logging-cases-and-fines/08-082016/22 (accessed: 02.07.2019). 
groups like anti-Balaka Movement (Central Africa) embarked on this kind of resource trafficking to generate direly needed revenue ${ }^{17}$. In the process of committing such transnational crimes, these groups use SALW to protect the movement of their subjects from one border location to the other. It is via this means that such weapons are allowed to proliferate across the borders and are then used to destabilize states and create insecurity in the different regions on the continent. SALW has greatly enhanced the trapping and killing of such wild animals like apes, pangolins and elephants [Vandome, Vines 2018]. Apes like gorillas, orangutans, bonobos and chimpanzees are targeted for both their meat and for human entertainment. Pangolins and elephants are targeted for both their scales and tusks, respectively. These commands premium prices within the international markets. The accessibility of SALW has made it possible for this transnational criminals (poachers) to track and kill these animals with ease and has also made it easier for them to challenge and ward-off the rangers sent to check them [Krause 2015]. This has been the terrible situation for these wild animals in countries like Liberia, Nigeria, Ghana, Ethiopia, Mali, Sierra Leone, Uganda and Kenya.

4. Stolen Motor Vehicle Trafficking. There are of two types: intra- and inter-continental trafficking. Intra-continental deals with stolen vehicles that are trafficked within the continent from one border region to the other. This affects almost all the regions on the continent. The intercontinental dimension deals with those cars that are brought from Europe, North America and Asia into Africa. Different models of stolen cars, trucks and buses are trafficked within the continent. Stolen cars are driven across several borders for resale in final destination countries. For example, cars stolen in Uganda have been recovered in the Democratic Republic of the Congo and those stolen in Kenya and South Sudan were recovered in Uganda ${ }^{18}$. In West

17 Extending Arms Embargoes on Somalia, Eritrea, Security Council Adopts Resolution 2385 (2017) by 11 votes in Favour, 4 Abstentions // United Nations Publication. November 14, 2017. URL: https:/www.un.org/ press/en/2017/sc13065.doc.htm (accessed: 02.07.2019).

18 Interpol Recovers Seven Stolen Motor Vehicles // Daily Monitor. August 6, 2017. URL: http://www.monitor.
Africa, ECOWAS, the regional economic arrangement that has encouraged the free movement of people, goods and services across borders in the region has aided this kind of transnational crime in the region. Trafficking in stolen vehicles has aided the proliferation of SALW in West Africa because such weapons are sometimes smuggled through the porous borders into the countries in the region. Nigeria has been negatively impacted by this kind of crime. Stolen vehicles coming in from Benin and Ghana have been used to smuggle SALW into Nigeria at various times.

5. Maritime Piracy: Maritime piracy occurs in the Gulf of Guinea basin countries in West and Central Africa and the shores of the Gulf of Aden and horn of Africa countries in the East. Piracy is particularly deadly on the continent because it not only leads to disruption in intraand inter-continental maritime trade, it also drives the proliferation of SALW. Indeed, pirates on the continent have become very adept at kidnapping for ransoms, attacks on oil tankers and vessels, and hijacking and boarding of cargo vessels. To this mix has been added the trafficking of illicit SALW. In almost all the attacks, the weapon of choice of the perpetrators has always been SALW. The easy accessibility and portability of SALW on the continent have facilitated and enabled the high incidence of piracy on the waters in Africa. In 2017, there were 7 incidents involving a vessel coming under fire in the Gulf of Guinea ${ }^{19}$. In the Niger Delta of Nigeria, pirates attack oil tankers to steal the crude which are then sold to refineries in both the country and the West African sub-region ${ }^{20}$.

co.ug/News/National/Interpol-recover-seven-stolen-motorvehicles/688334-4047128-23jpjr/index.html (accessed: 02.07.2019).

${ }^{19}$ Off West Africa, Navies Team Up in Fight Against Piracy // Times Live. March 7, 2018. URL: https://www.timeslive.co.za/news/africa/2018-03-07-offwest-africa-navies-team-up-in-fight-against-piracy (accessed: 02.07.2019).

${ }^{20}$ Maritime Piracy Hotspots Persist Worldwide despite Reductions in Key areas // International Chambers of Commerce. February 2, 2016. URL: https://www.icc-ccs. org/index.php/1154-imb-maritime-piracy-hotspots-persistworldwide-despite-reductions-in-key-areas (accessed: 02.07.2019). 
Maritime pirates in all the regions in Africa rely heavily on the SALW in carrying-out their nefarious transnational activities.

\section{Impacts of Transnational Crime in Africa}

Transnational crime has affected socioeconomic and political development in Africa. In its various formats, transnational crime has ensured that the issues of governance, security, socio-economic and political development have become intractable on the continent. The following is the analysis of how transnational crime has retarded social, economic and political growth and development in Africa.

1. Impact on Governance. Transnational crime has made the issues of governance and legitimacy an onerous one for the different governments in Africa [Shaw 2014: 93-99]. The proliferation of SALW has aided the growth and spread of transnational criminals on ungoverned spaces in countries on the continent. These ungoverned spaces, usually in the border regions, have allowed transnational criminal enterprises such as human, arms and drug trafficking to fester and flourish.

In some cases, these transnational criminal enterprises have been responsible for the economic survival and sustenance of most communities and towns in the periphery of the states. This means that such communities allegiances will not be to the states but to the perpetrators of such transnational criminal enterprises that is responsible for their socioeconomic survival. Once any of these transnational criminal enterprises has been sufficiently developed, it will affect the relationship between the constitutionally recognized authority in the state and the citizens in this border region. In the long-term, this will affect the overall ability of the government to exercise control over all the regions in the state since its legitimacy will now be in doubt [Bruinsma 2015]. This impact of transnational crime is being felt in the West African countries like Nigeria, Chad, Mali and Niger and in Somalia in East Africa.

2. Impact on conflict. The transnational crime of trafficking in SALW has affected both the duration, character and intensity of conflicts in Africa. The proliferation and portability of SALW has made the phenomenon of child soldiers to become a permanent feature of conflicts on the continent. For example, civil conflicts in Liberia, Sierra Leone, Uganda and the Democratic Republic of the Congo have witnessed the use of children as active combatants using SALW like pistols, AK-47 and rifles. Being the first weapons of choice for both state and non-state combatants on continent, SALW has made it possible for non-state actors like militants, terrorists and herders to effectively challenge states in conventional engagements. This is true for the conflict situation in the West African state of Nigeria in its confrontation with the terrorist group known as Boko Haram. This is also true for the long-running conflict between the Lord's Resistance Army (LRA) and the Ugandan security forces in East Africa. The point here is that the easy access to SALW and its trafficking across the different porous borders on the continent is a major factor responsible for the high incidences and long duration of conflicts on the continent.

3. Impact on Security. The widespread availability of trafficked SALW on the continent has created serious human security challenges. This is because the presence of such weapons has encouraged state and non-state actors to readily resort to violence and force rather than negotiation, diplomacy and persuasion to resolve their differences ${ }^{21}$. The unregistered nature of such weapons makes it easier for both state and non-state actors to use such to violate human rights and international humanitarian law. Additionally, since most states in Africa did not have credible and viable disarmament and demobilization programs at the end of any major conflict, SALW in the hands of the erstwhile combatants then become a tool that enables the commission of transnational crime like hijacking, piracy, arms, drug and human trafficking.

21 Integrated Disarmament, Demobilization and Reintegration Standards: Module 4.11 SALW Control, Security and Development // United Nations Inter-Agency Working Group on Disarmament, Demobilization and Reintegration (UNDDR). 2006. URL: http://www.poa-iss. org/BPD/Upload/IDDRS_411.pdf (accessed: 02.07.2019). 
4. Impact on Socio-Economic Development. Transnational crime is a major factor responsible for socio-economic underdevelopment in Africa [Shaw, Wannenburg 2005: 368-386]. Socioeconomic underdevelopment in developmental studies is a breeding ground for most of the vices that confronts Africa. Poverty, social and economic inequality in the different societies in Africa encourages perpetrators to engage in transnational crime to the detriment of the states. It has also encouraged the proliferation of SALW that has the multiplier effect of the commission and enablement of other transnational crime like piracy, human and drug trafficking. The longterm costs of SALW in terms of human and economic development affect societies as a whole; and the adverse effects on armed violence on poverty, social spending and economic development perpetuates human suffering. This affects the overall impact on human development, knowledge and education, income, standard of living and community participation ${ }^{22}$.

\section{Recommendations}

Since the challenges posed by the proliferation of SALW and transnational crime in Africa are interconnected and intertwined, it is only logical for the countries on the continent to provide solutions that will tackle the two concurrently and simultaneously. In order for the governments on the continent to be able to proactively and effectively curb and contain the proliferation of both SALW and transnational crime, they will have to:

1. Establish a continent-wide database that can identify the different transnational organizations, their mode of operations, specific transnational criminal enterprise and the form of their strategic alliances. This is necessary because as my research has shown, transnational crime is a scourge that affects the whole of Africa, but each region experience different shades of the crime. For example, maritime

${ }^{22}$ People Safe from Guns in South Sudan: A Training for Local Stakeholders // Bonn International Centre for Conversion (BICC). 2005. URL: https://www.bicc.de/ uploads/tx_bicctools/salw_booklet_sudan.pdf (accessed: 02.07.2019). piracy and oil smuggling are two transnational crime that affects East and West Africa more compared to the other regions [Siebels 2020]. Animal poaching is more restricted to East and South Africa. Hence, the assertion that a continent-wide database will have to be established to identify the transnational crime that is specific to a particular region so that it can be easier to provide targeted solutions.

2. At the regional level, effort must be made to strengthen legislations and laws that have already been created to tackle transnational crime and the proliferation of SALW. Where such laws and legislations exist, they must be judiciously and rigorously implemented. A cursory look at some of the extant literature on the prevention of transnational crime and the proliferation of SALW show that such laws and legislations exist [Idowu 2019: 28]. However, they are largely observed in the breach. For example, ECOWAS has such a legislation called Convention on Small Arms and Light Weapons, Their Ammunition and Other Related Materials ${ }^{23}$ signed in 2006 and entered into force in 2009 [Rogers 2009: 101] and Protocol Relating to the Mechanism for Conflict Prevention, Management, Resolution, Peacekeeping and Security ${ }^{24}$, signed in 1999 to tackle the proliferation of SALW. However, most of the member states have refused to fully enforce the provisions of the two laws ${ }^{25}$ because profits from such illegal

23 ECOWAS Convention on Small Arms and Light Weapons, Their Ammunition and Other Related Materials // SIPRI. June 14, 2006. URL: https://www.sipri.org/sites/ default/files/research/disarmament/dualuse/pdf-archive-att/ pdfs/ecowas-convention-on-small-arms-and-light-

weapons-their-ammunition-and-other-related-materials.pdf (accessed: 02.07.2019).

${ }^{24}$ ECOWAS Protocol Relating to the Mechanism for Conflict Prevention, Management, Resolution, Peacekeeping and Security. December 10, 1999. URL: https:/www.zif-berlin.org/fileadmin/uploads/analyse/ dokumente/ECOWAS_Protocol_ConflictPrevention.pdf (accessed: 02.07.2019).

${ }^{25}$ Berkol I. Analysis of the ECOWAS Convention on Small Arms and Light Weapons and recommendations for the development of an Action Plan // Group for Research and Information on Peace and security (GRIP). April 1, 2007. URL: http://archive.grip.org/en/siteweb/images/ NOTES_ANALYSE/2007/NA_2007-04-01_EN_IBERKOL.PDF (accessed: 02.07.2019). 
trades are veritable sources of needed revenue for some of these states.

3. Since transnational crime is a crime that negatively affects every state in the different regions, it will be necessary for countries on the continent to intensify interagency coordination and cooperation. This will facilitate the pooling of the scarce but crucial resources that are needed to curb and contain the proliferation of SALW and the commission of transnational crime. Importantly, such interagency coordination and cooperation will enhance the timely dissemination of vital information and intelligence that will be needed to create and deploy effective institutional mechanism to curb and contain the twin menace.

\section{Conclusion}

Transnational crime is not a uniquely African phenomenon. It is felt in the different continents of the world in varying degrees. However, a combination of factors such as a dysfunctional political system, poverty, illequipped security forces, well organized criminal groups and porous borders have made its effects to be more pronounced in Africa. In the same vein, the easy access, unregulated nature and portability of SALW has made it possible for perpetrators to commit the different variants of the crime in Africa. Small arms and light weapons have both enabled and ensured the commission of transnational crime like human and drugs trafficking, maritime piracy and arms trafficking in Africa. Guns like SALW are not just used to commit transnational crime but they also enable it. In other for Africa to be able to escape its unending transnational crime and conflict traps, concerted effort is needed to holistically and effectively tackle the problem of the proliferation of SALW.

Received / Поступила в редакцию: 20.01.2019 Accepted / Принята к публикации: 16.02.2020

\section{References / Библиографический список}

Ayissi, A. \& Sall, I. (2005). Combating the Proliferation of Small Arms and Light Weapons in West Africa: Handbook for the Training of Armed and Security Forces. United Nations: Programme for Coordination and Assistance for Development, United Nations Institute for Disarmament Research (UNIDIR). URL: https:/unidir.org/files/publications/pdfs/combating-the-proliferation-of-small-arms-and-light-weapons-in-westafrica-handbook-for-the-training-of-armed-and-security-forces-326.pdf (accessed: 02.07.2019).

Bourne, M. (2005). The Proliferation of Small Arms and Light Weapons. In: Krahmann, E. (Eds.). New Threats and New Actors in International Security. New York: Palgrave Macmillan. P. 155-176. DOI: 10.1057/ $9781403981660 \_8$

Brown, S.S. (2020). Introduction: Setting the Stage. In: Brown, S.S. \& Hermann, M.G. Transnational Crime and Black Spots: Rethinking Sovereignty and Global Economy. UK: Palgrave Macmillan. P. 1-12. DOI: 10.1057/ 978-1-137-49670-6_1

Bruinsma, G. (2015). Histories of Transnational Crime. New York: Springer-Verlag. DOI: 10.1007/978-1-49392471-4

Chelule, E. (2014). Proliferation of Small Arms and Light Weapons: Challenge to Peace, Development and Security in Africa. IOSR Journal of Humanities and Social Sciences (IOSR-JHSS), 19 (5), 80 - 87. DOI: 10.9790/083719558087

Ellis, S. \& Shaw, M. (2015). Does Organized Crime Exist in Africa? African Affairs, 114 (457), 505-528. DOI: 10.1093/afraf/adv035

Idowu, O.I. (2019). Legal and Regulatory Challenges to Effective Implementation of the Fireams Act in Nigeria. Ede: Journal of Humanities and Social Sciences, 1 (2), 26-39.

Jeffrey, B. \& Klare, M. (1998). Small Arms and Light Weapons: Controlling the Real Instruments of War. Arms Control Today. URL: https://www.armscontrol.org/act/1998 08-09/mkas98 (accessed: 02.07.2019).

Keili, F.L. (2008). Small Arms and Light Weapons Transfer in West Africa: A Stock-Taking. Disarmament Forum. URL: https://www.unidir.org/files/publications/pdfs/the-complex-dynamics-of-small-arms-in-west-africa-en329.pdf (accessed: 02.07.2019).

Krause, K. (2015). Small Arms Survey: Weapons and the World. Cambridge: Cambridge University Press. 
Kumar, S. (2008). Small Arms and Light Weapons: A Global Health to Human Security and Development. The Indian Journal of Political Science, 69 (4), 787-800.

Lloyd, P., Simmons, B. \& Stewart, B. (2012). Combating Transnational Crime: The Role of Learning and Norm Diffusion in the Current Rule of Law Wave. In: Nolkaemper, A., Zurn, M. \& Peerenboom, R. (Eds.). Rule of Law Dynamics. In an Era of International and Transnational Governance. Cambridge: Cambridge University Press. P. 153-180. DOI: 10.1017/CBO9781139175937.011

Madsen, F. (2009). Transnational Organized Crime. New York: Routledge. DOI: 10.4324/9780203875827

Mystris, D. (2019). Transnational Crime in the African Union. In: Mitsilegas, V., Hufnagel, S. \& Moiseienko, A. (Eds.). Research Handbook on Transnational Crime. Edward Elgar Publishing. P. 482 -488. DOI: $10.4337 / 9781784719449$

OECD. (2018). Illicit Financial Flows: The Economy of Illicit Trade in West Africa. OECD Publishing, Paris. DOI: 10.1787/9789264268418-en

Pumphrey, C. \& Schwartz-Barcett, R. (2003). Armed Conflict in Africa. Scarecrow Press.

Reitano, T. (2018). Organized Crime as a Threat to Sustainable Development: Understanding the Evidence. In: Comolli, V. (Eds.). Organized Crime and Illicit Trade: How to Respond to this Strategic Challenge in Old and New Domains. New York: Palgrave Macmillan. P. 23-35. DOI: 10.1007/978-3-319-72968-8_2

Rogers, D. (2009). Postinternationalism and Small Arms Control: Theory, Politics, Security. Bodmin: Ashgate. DOI: $10.4324 / 9781315601687$

Shaw, M. \& Wannenburg, G. (2005). Organized Crime in Africa. In: Reichel, P. \& Albanese, J. (Eds.). Handbook of Transnational Crime and Justice. Thousand Oaks, CA: SAGE Publications Inc. P. 367-386. DOI: $10.4135 / 9781412976183 . n 18$

Shaw, M. (2014). Transnational Organized Crime in Africa. In: Albanese, J. \& Reichel, P. (Eds.). Transnational Organized Crime: An Overview from Six Continents. Thousand Oaks, CA: SAGE Publications Inc. P. 93-117. DOI: 10.4135/9781483349091.n6

Sheptycki, J. \& Wardack, A. (2005). Transnational and Comparative Criminology. London: Glasshouse. DOI: $10.4324 / 9781843146049$

Siebels, D. (2020). Maritime Security in East and West Africa: A Tale of Two Regions. Switzerland: Palgrave Pivot. DOI: $10.1007 / 978-3-030-22688-6$

Stoica, I. (2016). Transnational Organized Crime: An (Inter)national Security Perspective. Journal of Defence Resources Management, 7 (2), 14-15.

Vandome, C. \& Vines, A. (2018). Tackling Illegal Wildlife Trade in Africa: Economic Incentives and Approaches. The Royal Institute of International Affairs. URL: https://www.chathamhouse.org/sites/default/files/ publications/2018-10-11-VandomeVines-Illegal-wildlife-WEB.pdf (accessed: 09.01.2020).

Zabyelina, Y. (2009). Transnational Organized Crime in International Relations. Central European Journal of International and Security Studies, 3 (1), 11-22. About the author: Falode Adewunmi James — PhD, Department of History and International Studies, Lagos State
University, Nigeria (e-mail: adewunmi.falode@lasu.edu.ng).

Сведения об авторе: Фалоде Адевунми Джеймс - доктор философии, доцент кафедры истории и международных отношений Государственного университета Лагоса, Нигерия (e-mail: adewunmi.falode@lasu.edu.ng). 